Journal of Economics and Behavioral Studies

Vol. 5, No. 2, pp. 57-68, Feb 2013 (ISSN: 2220-6140)

\title{
Estimating the Costs and Benefits of a Common Currency for the Second West African Monetary Zone (WAMZ)
}

\author{
Harrison Oluchukwu Okafor \\ National Institute for Legislative Studies, National Assembly, Abuja, Nigeria \\ agiboy2000@yahoo.com
}

\begin{abstract}
This paper, estimates the costs and benefits of a common currency in WAMZ. Behavioral models capturing the elements of costs (asymmetric shocks, loss of monetary policy autonomy, and fiscal policy distortion), and benefits (trade creation, financial integration effects and policy coordination gains) were estimated using the Vector Auto-regression (VAR) procedure and panel estimation technique.VAR impulse response and forecast error method was used to determine the countries' response to shocks while panel regression technique was used to estimate other behavioral equations. Fiscal policy distortion and loss of monetary policy autonomy are the main cost of monetary union in the zone while the potential trade creation gain is marginal. High disposition to money reserve and weak revenue base are the core determinants of fiscal policy distortion in the zone. Overall, the paper concludes that fiscal policy distortion constitutes serious policy challenge to monetary union in the zone. Dealing with this challenge may require short-run systematic macroeconomic adjustments to enhance the convergence of macroeconomic policy indicators in the zone.
\end{abstract}

Keywords: Behavioral Models, Monetary Policy Autonomy, Fiscal Policy Distortion and Asymmetric Shocks

\section{Introduction}

Since the influential work of Mundel (1961) on Optimum Currency Area (OCA), the elimination of national currencies and their replacement by a common regional currency have continued to be a topical subject. The reasons for a monetary union range from wanting to promote regional solidarity and integration to fears those independent national currencies may be subject to destabilizing speculations and attacks (Debrun, Masson and Pattillo, 2005). Mundel (1961) laid the theoretical foundation for the basic economic and political considerations why countries should adopt a common currency. The economic consideration appears rather, to be the over-bearing factor for regional integration concerns as demonstrated by the European Monetary Union (EMU) and this has stimulated interests among other regional blocks across the globe. The Economic Community of the West African States (ECOWAS) was established in 1975 with the primary objective of forging a strong economic and monetary integration in the sub-region. The community comprises of fifteen nations, namely Benin, Burkina Faso, Cape Verde, Cote d'Ivoire, Gambia, Ghana, Guinea, Guinea-Bissau, Liberia, Mali, Nigeria, Niger, Senegal, Sierra Leone and Togo. The ECOWAS project was aimed at widening regional markets and opportunities in trade, and to promote financial and monetary stability in the region. Through the establishment of a common market and adoption of a common currency, the ECOWAS integration ${ }^{1}$ arrangement was expected to accelerate economic growth and transformation of the sub-region with the overall aim of alleviating poverty among the people. ECOWAS is divided into two main blocks: the West Africa Economic and Monetary Union (WAEMU) zone that shares a common currency with the Central Africa Economic and Monetary Union (CAEMU): the CFA zone, and the non-WAEMU countries that uses' their separate national currencies.

${ }^{1}$ Integration of economies cover economic integration/Preferential Trade Agreements (PTA) for instance, ACP-EEC Lome convention, Free Trade Area (NAFTA, LAFTA), Custom Union (CET), Common Market (EEC) and Monetary Union which is the last stage. 
At the initial stage, the community adopted a protocol known as the ECOWAS Monetary Co-operation Program (EMCP) in 1987. The EMCP was designed to strengthen the achievement of the common currency and common central bank framework. Nevertheless, lack of commitment, non-uniform adoption of required macroeconomic framework, and lack of policy coordination and harmonization between the CFA Franc zone and the non-CFA franc zone countries have been major obstacles to the implementation of the project. Interests of recent studies have linked these constraints to poor institutional factors and poor economic performance of member states (Balogun, 2008 and ECOWAS, 2005). However, since the successful launch of the EMU in 1999, a great deal of interest has been renewed on monetary union in ECOWAS and other regions across the world (Masson and Pattillo, 2004). The Second West African Monetary Zone (WAMZ) comprising The Gambia, Ghana, Guinea, Nigeria and Sierra Leone was initiated in 1999 to fast track the common monetary policy objective of ECOWAS. However, uncertainties about the potential economic costs and benefits have been major obstacles to the project. Over the past five decades, controversy remains about the potential costs and benefits of a common currency among economists and policymakers. A major challenge for economists has been the development of analytical tools to test or adumbrate the potential costs and benefits of monetary union (Ogunkola, 2001). Despite the relatively growing body of empirical works on the costs and benefits of joining a monetary union (Emerson et al, 1992; Debrun, Masson and Pattillo, 2002 \& 2005), few available studies exist in the case of WAMZ and are very limited in scope. Most empirical studies in ECOWAS/WAMZ focused separately on the specific elements of costs and benefits of monetary union. This study, therefore, seeks to estimate the costs and benefits of a common currency in WAMZ. Following this introduction, section 2 presents a robust survey and review of the literature on the costs and benefits of monetary union with emphasis on WAMZ. Section 3 expounds on the analytical framework and estimation techniques. Empirical evidence on the costs and benefits of a common currency in WAMZ is the focus of section 4, while section 5 provides policy implication of the findings and conclusion.

\section{Literature Review}

The issues relating to the costs and benefits of monetary union emanates from the OCA theory due to Mundel (1961), McKinnon (1963), Kenen (1969) and Ingram (1972). The theory espouses the conditions under which a region or group of countries qualify as an optimum currency area as basis for assessing the expected net-benefit of monetary union. An optimum currency area is defined as a group of countries with economies closely linked by trade in goods and services and by factor mobility (Krugman and Obstfeld, 2000). Thus, such group of countries or region may have similar economic structure and symmetric shocks simultaneously. In such arrangement, a common currency may become optimal for the entire region. The optimality of this theory is viewed as a case where the costs of relinquishing exchange rate as an internal instrument of adjustment are outweighed by the benefits of adopting a single currency or a fixed exchange rate regime (Ricci, 2008). Mundell (1961) proposed a simple idea to determine whether it can be costly or beneficial for countries in a region to create a common monetary area. He argued that fixed exchange rate among countries of a region could produce better results than the flexible exchange rate if they posses common characteristics. He maintained that when factor (labor) mobility that permits large fiscal transfer is present across a region, as well as the existence of flexible wage and prices among economies, asymmetric shocks would reduce in that region. Accordingly, countries could afford to lose their exchange rates as a tool of adjustment because exchange rate plays a passive role when a region is faced with symmetric shocks. McKinnon (1963) asserted that the more open the economy, the less the effectiveness of exchange rate as an adjustment instrument for correcting external imbalances. According to his reasoning, open economy bears close link with the law of purchasing power parity (PPP), indicating that exchange rate would affect most prices the same way and may not be able to generate the changes sought in relative prices. Kenen (1969) argued that the more diversified the production structure of a country, the less the likelihood of asymmetric shocks and the less important it is to depend on exchange rate in adjustments during recession period.

Intuitively, when a group of countries satisfy these criteria, they constitute an OCA. The emphasis is that the OCA would lead to symmetric and synchronous business cycles and shocks among the countries. Hence, exchange rate as an adjustment tool becomes ineffective and unnecessary. Whether it is appropriate is a question for empirical analysis. The major theoretical challenge has been to reconcile these criteria with the associated costs of relinquishing independent monetary policy sovereignty against the benefits of a common 
currency. In the literature, the probability of shocks and consequences in a monetary union has created a sharp divide among economists. The contention of the OCA theory implies that a region with substantial asymmetric shock may be difficult to sustain a monetary union. A nexus drawn from the OCA theory and the criteria suggests that asymmetric shocks do not make monetary union beneficial. Asymmetric shocks are those shocks that affect members in a non-synchronous manner (Krugman and Obstfeld, 2000). Differences in economic structures are likely to account for such asymmetries (Bergman, 1999). According to Kenen (2004), asymmetries often result due to non-correlation of business cycles from trade divergences, and domestic factors resulting from productivity and supply idiosyncrasies. As Coleman (1999) points out, this could be the reason why high degree of correlation of business cycles is by many seen as a necessary condition for entering into a monetary union. However, evidence from the Endogenous/New Optimum Currency Area (NOCA) due to Frankel and Rose (1998) and Rose (2000) suggest that greater economic and monetary integration can lead to a more intra-regional trade that could foster synchronous shocks and business cycles. The thrust of this view is that regions that do not constitute an OCA ex ante could become one ex post. The economic implication is that economic and monetary integration could enhance the convergence of economies, hence reduce the costs due to shocks asymmetries among potential members of a monetary union. Despite these glaring contributions, the NOCA theory could not directly account for the costs associated with the loss of autonomous policy instruments as well as other benefits expected in joining a monetary union. It is also difficult to conclude whether any set of partnering countries could form a currency union and just wait for the deeper integration to occur almost automatically and inevitably reap net-benefits from a single currency (Mongelli, 2005).

Major advances in the literature to deal with these complexities have extended to the identification and analysis of specific elements of costs and benefits of monetary union. Forming a currency area with a group of partner countries entails the loss of direct control over the national monetary policy and the exchange rate De Grauwe, (2000), Kronbenger, (2004), De Grauwe and Mongelli (2005), Debrun, Masson and Pattillo (2005) and Zika (2006). This entails forsaking expenditure switching policies Mongelli (2002). A novel from recent theoretical views on the optimality of a common currency suggests that fiscal policy distortions are serious costs to forming a monetary union Masson and Pattillo (2004), Debrun, et al. (2005, 2010), Zika (2006) and Hefeker (2008). Trade creation, financial and capital efficiency effect as well as the gains from policy coordination are the main benefits of monetary union De Grauwe, (2000), Mongelli, (2002), De Grauwe and Mongelli (2005), Kronberger, (2004) Debrun, Masson and Pattillo, (DMP) (2005 and 2010). A critical challenge in the literature is ability to use a one-off model to estimate the costs and benefits of common currency. Nonetheless, different models have been developed to estimate different elements of costs and benefits of monetary union in the literature. Bayoumi and Eichengreen (1992), Bergman (1999), FerrarhiFilho (2001), DMP (2005) and Ogunkola (2005) utilized shocks based models to estimate the costs of monetary union. Frankel and Rose (1998), Rose (2000) and Nnanna, et el. (2007) employed the gravity model to predict the trade creation gains of monetary union. Nnanna, et el. (2007) utilized the endogenous growth model to measure the financial integration effect of MU. Moreover, the literature is replete with plethora of empirical evidence on the potential costs and benefits of monetary union across the globe. Bayoumi and Eichengreen (1992) found more idiosyncratic shocks across European Communities than in the United States. The result of the standard deviation indicates that output fluctuations have generally been somewhat smaller across European communities than across US region, while inflation variability has been higher in Europe. The authors predict that the EMU may be costly on account of asymmetries. Bergman (1999) reported that the Scandinavian Currency Union (SCU) does not qualify to be a monetary union in the face of their countryspecific shock asymmetries and poor economic structures that are relatively not open to foreign trade. In the case of the MERCOSUR countries, Ferrari-Filho (2002) reveals that it does not make economic sense to create a monetary union.

Masson and Pattillo (2001) found large movement of terms of trade and high negative correlation of shocks for several ECOWAS countries particularly WAMZ nations. They concluded that monetary union could be costly in the zone. Similar predictions were reached by Masson and Pattillo (2004), IMF, (2005) and Debrun, Masson and Pattillo (2005). However, Ogunkola and Jerome (2005) and Ogunkola (2005) in a different approach acknowledged the viability and capability of the project to boost inter and intra-regional trade in ECOWAS. Others studies including Soyibo, (2000), Ogunkola (2001), Iyoha, (2003), and Ogunkola and Jerome 
(2005) point that monetary integration could be beneficial in ECOWAS. Ogunkola (2005) revealed that loss of seigniorage is a potential cost to the ECOWAS monetary integration particularly the non-CFA zone. The study indicates that Ghana recorded over 4.35 percent average seigniorage to GDP during the period 1970 and 1985 while Nigeria reached over 4.22 percent during 1986 and 1994 as the countries with highest seigniorage to GDP ratios. Seigniorage to GDP ratio was also found to be very high in Sierra Leone, while Gambia had a moderate growth of seigniorage during the period under review. Niger, Togo and Senegal were among countries in the CFA zone that had the lowest siegniorage to GDP ratio. This result confirm the conclusions of Easterly (1999), Debrun, Masson and Pattillo, (2005) and Hefeker, (2008) that the non-CFA zone (WAMZ) relies so much on seigniorage revenue than the CFA countries. Masson and Pattillo (2001) study covering 1995 and 1998 established that seigniorage as policy handle is greater in WAMZ than the CFA. However, they found substantial decline around 0.9 percent in Nigeria, 1.4 percent Gambia and Sierra Leone seigniorage to GDP ratio while Ghana recorded 2.8 percent higher than all countries in both the WAEMU and non-WAEMU countries. As a general rule, seigniorage in excess of 1.5 percent of GDP is risky because the economy will eventually fall into inflation trap and seigniorage in excess of 3 percent indicates major macroeconomic imbalances (Blanchard and Fischer, 1989, Easterly, 1999 and World bank, 1994). The overall implication of these is that countries with high seigniorage demand would find it very costly to join a monetary union.

Furthermore, empirical findings on the trade creation impacts of monetary union suggest mixed result across regions and among authors. Following the earlier predictions of Emerson, et al. (1992) in the report "One market, One money", Frankel and Rose (1998) and De Grauwe (2000), Rose (2000) applying the gravity model report that intra-regional trade would increase by $3 \%$ due to the effect of monetary integration after controlling for the effects of exchange rate volatility in the EMU. Several studies including Glick and Rose (2001), Rose and Engel (2001) De Grauwe and Mongelli (2005), and Mongelli (2002 \& 2010) also confirm the result known as the "Rose effect". Nnanna, Essien, Onwioduokit and Adamgbe (2007) using gravity model for the second west African zone (WAMZ) find that intra-regional trade would increase by 13.3 percent due to the cumulative impact of market size after controlling for the impact economic and monetary integration with some instruments. World Bank (2008) also report that globalization has further increase intra-regional trade in the sub-Saharan African region. Mongelli (2010) asserts that the launch of the euro has brought a significant deepening of financial integration, albeit unevenly across financial market segments in Europe. Financial integration generates several widely accepted benefits such as the improved allocation of capital, higher efficiency of capital and higher economic growth Kronberger (2004), Mongelli (2005), and Ogunleye (2008). Ogunleye (2008) found a marginal positive impact of financial globalization on growth in subSaharan African countries. The result traced about 99 percent impact of growth to financial openness used to proxy globalization for Nigeria. In the case of WAMZ, Nnanna, et al. (2007) reports a cumulate negative 4.17 basic point of financial indicator on growth. The result reveals that credit to private sector and interest rate differential has a negligible impact of -0.147 and -0.255 percentage effects on growth as key indicators of financial development in WAMZ. The result, however, could not ascertain the individual country benefits from monetary integration.

Debrun, Masson and Pattillo (2005 \& 2010) examined the impact of monetary union on inflation. They find fiscal financing need as a critical factor that underpins inflation in the sub-Saharan African, which indirectly implies that giving up monetary autonomy through an independent regional central bank can act as an agency of restraint Collier (1991), and Baldwin, (1998). They argued that monetary union restrains monetary authority from financing fiscal deficit that manifest inflation. Further evidence suggests that output growth effect is another indicator of macroeconomic stability arising from the network effects of monetary unification. In summary, there appears some measure of consensus and divergences regarding the empirical evidence of costs and benefits of forming monetary union across regions and countries. Thus, there exist gaps in both the theoretical, methodological and empirical literature over the costs and benefits of monetary union. The two baseline theories of a common currency are separately inadequate to provide robust analytical apparatus on the costs and benefits of monetary union. None of the empirical studies examined covered both the elements of costs and benefits of a common currency particular in the second West African Monetary Zone. 


\section{Methodology}

We developed behavioral models to estimate the costs elements (asymmetric shock, loss of monetary policy autonomy and fiscal policy distortion), and benefits elements (trade creation, capital efficiency effects and policy coordination gain). These models are presented below:

Asymmetric Shock Model: The asymmetric shock model follows from the WAMI, (2005) and Debrun, Masson and Pattillo (2005) framework. However, our approach contrasts with these authors in two ways; the process of generating shocks and the variables used are sufficiently different. Following the prevalence of asymmetric shock to terms of trade in the zone, we examine the response of exchange rate to terms of trade shock to evaluate the cost implication of asymmetry shocks in WAMZ. Ricci (2008) stressed that the degree to which asymmetric shocks implies a large cost to a currency union depends on the effectiveness of exchange rate as an instrument of short-run adjustment. Therefore, the model is anchored on the structural variance decomposition vector auto regression VAR framework developed by Sim (1980) and Bayoumi and Eichengreen (1992) expressed as;

$$
\begin{aligned}
\Delta Y_{t} & =\alpha_{0}+\sum_{i=1}^{k} \alpha_{i} \Delta X_{t-1}+\sum_{i=1}^{k} b_{j} \Delta Y_{t-j}+v_{t} \\
\Delta X_{t} & =\alpha_{0}+\sum_{i=1}^{k} \alpha_{i} \Delta Y_{t-1}+\sum_{i=1}^{k} b_{j} \Delta X_{t-j}+v_{t}
\end{aligned}
$$

Where $Y_{t}$ represents exchange rate and $X_{t}$ is the term of trade shock TOT .The procedure starts with generating the shock by regressing each variable to its own lagged values and the lagged values of the other taking the error terms as shocks $\left(X_{t}=B_{1} X_{t-1}+B_{2} X_{t-2}+\ldots+B_{n} X_{t-n}+e_{t}\right.$ in the form of the Bayoumi and Eichengreen, 1992). The second step is to examine the nature of the response of exchange rate to the terms of trade shock through the variance decomposition technique. This approach is consistent with WAMI (2005).

Loss of Monetary Policy Autonomy Model: Following Aisen and Veiga (2005) seigniorage model, we specify the equation below to measure the impact of loss of monetary policy autonomy associated with monetary union as:

$$
M R / G D P=\alpha_{1}+\alpha_{2} G R / G D P+\alpha_{3} O P N S+\alpha_{4} G D P P C+\alpha_{5} P D / G D P+\alpha_{6} E X P / G D P+\varepsilon
$$

Where $M_{r}$ is money reserve used to capture money creation, $G R / G D P=$ government revenue to gross domestic product, $P D / G D P=$ public domestic debt to gross domestic product, $O P N S=$ openness of the economy, $G D P G R=$ growth rate of gross domestic product per capita, $E X P / G D P=$ government expenditure to gross domestic product and $\varepsilon$ is the stochastic error term that accounts for other unexplained variations in the model.

Fiscal Policy Distortion Model: The model for fiscal policy distortion is developed to account for the cost implication of budget deficit financing in monetary unification. The model leans on the revenue model of Debrun, Masson and Pattillo (2010). However, we modified the model to express budget deficit financing as a function of the policy control variables. This model is specified as;

$$
C G / G D P=\chi_{1}+\chi_{2} M R / G D P+\chi_{3} F D / G D P+\chi_{4} C A B / G D P+\chi_{5} P D / G D P+\varepsilon
$$

Where, $C G / G D P$ is defined as domestic credit to the government sector used to capture deficit financing. The variables $F D / G D P$ represents fiscal deficit to GDP ratio, $M R / G D P=$ money reserve to GDP as a measure of money creation and $C A B / G D P$ = current account balance.

Trade Creation Model: The trade creation effect leans on the augmented gravity model of Nnanna, et al. (2007). The gravity model takes into consideration the effects of economic and political barriers on international trade such that when these factors are endogenized, they increase intra-regional trade. Gravity model is highly flexible and takes care of the specific character of any region or zone. This model is consistent 
with several studies that sought to model the impact of monetary integration on trade in EMU, CFA, SADC and WAMZ economies (Emerson, et al 1992, Anyanwu, 2003 and Nnanna, et al 2007). The model specified as:

$$
\begin{gathered}
T F=\theta_{1}+\theta_{2} G D P s+\theta_{3} O P N S+\theta_{4} P O P+\theta_{5} T F_{-1}+\varepsilon_{i} \\
\theta_{2}, \theta_{3} \text { and } \theta_{4} \succ 0
\end{gathered}
$$

Where; GDP are the gross domestic products of the integrating countries, TF is defined as the trade flow variable. OPNS and POP are the openness and population variables used to dummy for the effect of monetary integration. Generally, these variables are expected to significantly and positively influence trade under the simplified assumption earlier stated in the theoretical review.

Financial and Capital Integration Effect: The capital and financial integration model of this study is consistent with the capital efficiency framework of Nnanna et al. (2007). Financial integration helps to improve capital efficiency, which impacts directly on economic growth. In the WAMZ nation's economies, domestic financial markets are relatively not well developed but cross-border financial flow impinges on growth. Following Nnanna et al. (2007), capital efficiency model is specified as:

$g=\lambda_{1}+\lambda_{2} G C P S+\lambda_{3} I T S+\lambda_{4} E X C H R T+\lambda_{5} I N F L+\varepsilon_{i}$

Capital efficiency is measured by a vector of financial development variables, $Y$ and control variables $Z$ respectively. Where $\mathrm{g}$ is the real growth rate of output, $\mathrm{y}$ captures the credit to private sector, interest rate differential between lending and deposit rate for the financial integration model. The control variables are exchange rate and inflation, which capture the effect and mechanism through which financial variables impact on growth.

Gains from Policy Coordination: The gains of policy coordination associated with joining a monetary union is anchored on the price stability model. To estimate the effect of monetary union on inflation, we modify the model of Debrun, Masson and Pattillo (2010) based on the ability of monetary union to curtail national government spending. Inflation is expressed as a function of the average financing needs and the amount of intra-union trade. The rationale is that monetary union would influence the spending pattern of members through optimal fiscal-monetary interaction (see Dixit and Lambertini, (2001). In addition, inflation would be contained by the efficient trade interaction (openness) due to stable exchange rate. The price stability model is stated below:

$$
\begin{gathered}
\pi=\gamma_{1}+\gamma_{2} F N+\gamma_{3} \theta_{A, i}+\varepsilon \\
\gamma_{2} \prec 0, \text { and } \gamma_{3} \succ 0,
\end{gathered}
$$

Where the variables, $\pi, F N$ and $\theta_{A, i}$ are inflation, financing needs (government expenditure) and the trade flow variable (openness) among members of the union.

Data and Estimation Techniques: The data were collected from the IMF Financial Statistics yearbook. Given that the study involves a panel data analysis, the behavioral models were estimated based on the transform panel structure model with the matrix notation stated as;

$y_{i t}=\alpha+x_{i t}^{1} \beta+u_{i t}, i=1, \ldots, N ; t=1, \ldots, T$ and $u_{i t} \cup I I D\left(0, \sigma^{2} v\right)$

Where the $\alpha$ represents unknown parameters jointly estimated with $\beta$ while $i$ and $t$ denote the crosssection dimension and time-series dimension. The $x^{\prime} s$ are the variables for estimation as the $v_{i t}$ accounts for the stochastic disturbance component of the fixed error term that is independent and identically distributed. Finally, the vector autoregressive method VAR would also be employed to determine the degree of response of exchange rates to the terms of trade shock as a basis of establishing the costs associated with asymmetric shocks. The procedures started by generating the shocks through regressing the residual of the terms of trade and then trace the response of exchange rate through variance decomposition mechanism. The choice is influenced by the fact that when measuring shocks variation and transmission, VAR method remains the best technique as evident in the various studies that have utilized the technique (see, Bayoumi and Eichengreen, 
1992; Ogunkola, 2005; and WAMI, 2005). The study also applied a sensitivity test to obtain the standardized beta coefficients in tracing the individual impact of the variables.

\section{Results}

Unit Root Tests: The Levin, Lin and Chu common unit root test results for the panel also reveal evidence of stationary at levels for most variables while some at first difference. The results of the unit root tests are presented in the appendix.

Estimates of Costs of Monetary Union: The vector autoregressive (VAR) analysis result shows that a cholesky standard deviation shock in the terms of trade, on the average induces about $0.08 \%$ impulse or innovations in exchange rate in the zone within two lag period. The lag period was selected based on the traditional lag selection criteria (Akaike and Schwartz information) technique. The degree of response of exchange rate to change in the terms of trade is portrayed by the variance forecast error result. The evidence provided by this result is at variant with some earlier findings. For instance, Masson and Pattillo (2001) found large negative movement in the terms of trade for WAMZ nations. However, the result further corroborates the finding of Ogunkola (2005) that real exchange rate variance in ECOWAS particularly the non-CFA countries has considerably narrowed around the range of 0.09 to 0.115 in the post Structural Adjustment Period (SAP). WAMI (2005) reports evidence of modest response of the terms of trade shock due to improvement in the convergence criteria across the zone.

a) Asymmetric Shock

Table 1: Result of the Asymmetric Shock Model

\begin{tabular}{ll}
\hline DEXCHRT & WAMZ \\
\hline DTOT(-1) & 0.000 \\
& 0.08 \\
DTOT(-2)* & $0.012{ }^{*}$ Optimal lag length
\end{tabular}

Table 2: Result of Loss of MPA Model

\begin{tabular}{lcccc}
\hline \multicolumn{5}{l}{ Dependent Variable: D(MRRGDP) Data Series: 1980-2009 } \\
\hline Variable & Coefficient & t-ratio & Standardized Beta & P-value \\
C & -0.01 & -0.1289 & & 0.8977 \\
D(GRGDP) & -0.07 & -2.0054 & $(-0.23)$ & $0.0474^{*}$ \\
D(OPNES) & 0.057 & 36.0448 & $(0.20)$ & $0.0000^{*}$ \\
D(GDPPC) & -0.02 & -0.3893 & $(-0.08)$ & 0.6978 \\
D(PDGDP) & -0.01 & -0.1892 & $(-0.20)$ & 0.8503 \\
D(EXPGDP) & 0.03 & 0.9984 & $(0.04)$ & 0.3203 \\
R2 $=0.92$ & DW $=3.19$ & & & \\
\hline
\end{tabular}

Source: Author's Computation (2011) * significant at 5\%, Values in parentheses are the standardized beta.

Loss of Monetary Policy Autonomy (MPA): The result of the loss of seigniorage equation is quite revealing and presented in table 3. The fixed effect panel regression result shows significant relationship between money reserve and its explanatory variables. The coefficients of government revenue as a percentage of GDP, economic development measured by gross domestic product per capita and expenditure to GDP followed their hypothesized signs while openness and domestic public debt to GDP had unexpected signs. The coefficient of the degree of openness of economies in WAMZ is however, statistically significant at $5 \%$ level though with a small magnitude. Government revenue has a negative and statistically significant effect on money creation in WAMZ. Economic development had a positive effect but not statistically significant. The negative but low relationship between money reserve and government revenue confirm the hypothesis that the demand for money reserve (siegniorage) is influenced by the weak government revenue base in subSaharan Africa Easterly, (1999), Iyoha (2003), Debrun, Masson and Pattillo, (2005), and Hefeker (2008). 
Disposition to money creation has been the bane of monetary policy effectiveness in the zone. This is because, seigniorage is extracted to finance fiscal deficit of the polarized governments in the region. This result appears to represent the overall character of the West African economy and corroborate the findings of Neiberding (2004), Masson and Pattilo (2004) and Debrun, Masson and Pattillo (2010). This result is supported by the high R-squared of about 92 percent. However, the overall individual impacts of the variables in terms of the relative effects reveals that government revenue, the level of openness and domestic public debt exerts relatively high influence on money reserve/creation in the region.

Table 3: Result of the Panel Fiscal Policy Distortion Model

\begin{tabular}{lcclc}
\hline \multicolumn{5}{l}{ Dependent Variable: D(CGGDP) Data Series: $\mathbf{1 9 8 0 - 2 0 0 9}$} \\
\hline Variable & Coefficient & t-ratio & Standardized Beta & P-value \\
C & -1.2095 & -0.0904 & & 0.9282 \\
D(MRRGDP) & 2131.9 & 6.8989 & $(0.43)$ & $0.0000^{*}$ \\
D(FDGDP) & 6.3946 & 1.5237 & $(0.02)$ & 0.1315 \\
D(CABGDP) & -2.4618 & -1.0951 & $(-0.13)$ & 0.2767 \\
D(PDGDP) & 0.0308 & 0.0106 & $(0.02)$ & 0.9916 \\
R2 $=0.55 \quad$ DW $=3.1$ & & & \\
\hline
\end{tabular}

Source: Author's Computation (2011) * significant at 5\%, Values in parentheses are the standardized beta

Fiscal policy Distortion: The result of fiscal policy distortion equation is indicative as shown in table 4. The panel regression result shows that the coefficients of all the explanatory variables had their expected theoretical signs. However, the coefficient of money reserve is high and equally statistically significant at $5 \%$ level. Fiscal deficit and current account balance were statistically insignificant and negligible. The result follows the theoretical postulation that high money creation (seigniorage revenue) and adverse current account balance could influence deficit financing by the government. Apart from its statistical significant, the relative contribution of money creation is clearly larger than any other variable that influence domestic credit to the government in WAMZ. Specifically, money reserve has more impact on fiscal policy distortion in WAMZ. This result further re-affirm the views in the literature that high disposition in the use of money creation instruments influences fiscal deficit financing in the sub-Saharan African region (Easterly, 1999 and Hefeker, 2008). This result is consistent with the findings of Debrun, Masson and Pattillo $(2005,2010)$ and Hefeker (2008) that there is unambiguous evidence of fiscal policy distortion in WAMZ. The coefficient of determination indicates that about $0.38 \%$ of the variations in the domestic credit to the government are explained by the changes in the explanatory variables.

\section{Estimates of Benefits}

Trade Creation Model: The result of the gravity model of trade creation benefit is also evident. With regard to the group effect, the panel fixed effect regression analysis result of the gravity model reveals that all the explanatory variables except market size measured by the gross domestic product (GDP) and population had their hypothesized signs. The result shows a significant relationship between trade flow in WAMZ and openness of the economy as well as the lag of trade flow at 5\% levels. Market sizes measured by output (GDP) and population have negative and statistically insignificant effects on trade flow in the region. The implication is both variables are not key determinants of trade flow. This is result further corroborate the views of Debrun, Masson and Pattillo $(2005,2010)$ that the trade creation gain of monetary unification in the second west African monetary zone is likely to be less beneficial. Openness and lag of trade flow are statistically significant. Both variables were used as dummy variables in the estimation. In terms of relative contribution, it is evident that the lag of trade flow and openness are likely to account for greater impact on trade creation resulting from economic and monetary integration. The traditional wisdom is that monetary unification will monetary union may take some period lag to insulate trade creation in the integrating economies as evident in the result. Cumulatively, the overall impact of monetary union on trade creation arising from market size is 1.06 percent compared with the 13.3 percent found by Nnanna, et al. (2007). The economic intuition is that though monetary union has the capacity to enhance trade flow in WAMZ, the overall effect may not be 
substantial. This finding corroborates the prediction of (Debrun, Masson and Pattillo 2005 and 2010). The 95 percent goodness of the fit provides some measure of confidence to this result.

Table 4: Result of the Gravity (trade creation) model

\begin{tabular}{lllcl}
\hline \multicolumn{6}{l}{ Dependent Variable: D(TFLO) } & Data Series: & $\mathbf{1 9 8 0 - 2 0 0 9}$ & \\
\hline Variable & Coefficient & t-ratio & Standardized Beta & P-value \\
C & 0.0008 & 0.6220 & & 0.8797 \\
D(GDP) & -0.0035 & -0.1517 & $(-0.02)$ & 0.8797 \\
D(POP) & -05051.8 & -0.1695 & $(-0.01)$ & 0.8657 \\
D(OPNES) & 6364.2 & 3.1418 & $(0.09)$ & $0.0022^{*}$ \\
D(TFLO(-1)) & 0.9514 & 30.5075 & $(0.95)$ & $0.0000^{*}$ \\
R2=0.90 DW $=2.22$ & & &
\end{tabular}

Source: Author's Computation (2011) * significant at 5\%, Values in parentheses are the standardized beta.

Table 5: Result of the Capital Efficiency Model

\begin{tabular}{lcccc}
\hline \multicolumn{5}{l}{ Dependent Variable: D(GDPGR), Data Series: 1980-2009 } \\
\hline Variable & Coefficient & t-ratio & Standardized Beta & P-value \\
C & -0.0644 & -0.0960 & & 0.9236 \\
D(GCPS) & 0.0087 & 0.9544 & $(0.13)$ & 0.3420 \\
D(ITS) & 0.6205 & 1.9796 & $(0.11)$ & $0.0503^{*}$ \\
D(EXCHRT) & 0.0003 & 0.1283 & $(0.06)$ & 0.8981 \\
D(INFL) & 0.0073 & 0.3018 & $(0.01)$ & 0.7633 \\
R2 $=0.046$ & DW $=2.9$ & & &
\end{tabular}

Source: Author's Computation (2011) * significant at 5\%, Values in parentheses are the standardized beta

Financial and Capital Market Effects: Evidence from the capital efficiency growth model of the capital and financial market effects of the West African Monetary Zone (WAMZ) in Table 5 is quite revealing. The fixed effect panel result indicates that the explanatory variables (financial development indicators) do not strongly influence economic growth. Although the coefficients of the variables followed their hypothesized theoretical signs, only the coefficient of interest rate spread is statistically significant at $5 \%$ levels. The coefficient of interest rate spread is equally high while the coefficient of the growth rate of credit to the private sector (core index) of financial development is statistically insignificant. This result is not consistent with finding of Nnanna et al. (2007). Exchange rate and inflation rate variables used as control variables are statistically insignificant and have negligible impacts on economic growth. Capital efficiency is expected to be contingent upon efficient utilization of financial instrument propelled by monetary integration and financial globalization. This result is consonance with the findings of Ogunleye (2008) that financial globalization has not deeply influenced major macroeconomic indicators that affect growth but when these factors are fully integrated, they could propel the growth of the financial system in sub-Saharan Africa. Interestingly, the relative contribution of the growth rate of the credit to private sector is higher and followed closely by the spread in interest rate in WAMZ.

Policy Coordination Gains: The result of the policy coordination gain from the panel regression analysis shows a significant relationship between inflation rate and government expenditure to GDP. The sign of openness was unexpected as it did not follow its hypothesized theoretical sign. Similarly, the coefficient of openness is statistically insignificant and almost negligible. The result reveals that monetary integration could influence government spending given the statistical relationship between policy control variable (inflation) and government expenditure. The implication is that monetary union may help in strengthening government fiscal expenditures. It is, however, instructive to note that the relative contributions of the explanatory variables are negligible in terms of the effect on the control variable. Theoretically, it is expected that economic integration would further the increase the level of openness of the economies that could help to improve trade tax and strengthen inflationary trends. This result seems to reject this hypothesis and 
further validates the prediction of Debrun, Masson and Pattillo (2010) that the expected gains from trade creation may be inconsequential in the African regional integration schemes.

Table 6: Policy Coordination Model Result

\begin{tabular}{|c|c|c|c|c|}
\hline \multicolumn{5}{|c|}{ Dependent Variable: D(INFL), Data Series: 1980-2009 } \\
\hline Variable & Coefficient & t-ratio & Standardized Beta & P-value \\
\hline $\mathrm{C}$ & 52.5800 & 6.8570 & & 0.0000 \\
\hline D(EXPGDP) & -1.1433 & -3.7031 & $(-0.03)$ & $0.0003^{*}$ \\
\hline $\mathrm{D}(\mathrm{OPNES})$ & -0.0325 & -0.0811 & $(-0.04)$ & 0.9355 \\
\hline $\mathrm{R} 2=0.23$ & $\mathrm{DW}=1.34$ & & & \\
\hline
\end{tabular}

Source: Author's Computation (2011) * significant at 5\%, Values in parentheses are the standardized beta.

Discussion of Results: The results indicate that the adoption of a common currency in WAMZ could have less potential trade flow and financial development effects. This highlights the fact that countries of the zone have similar economic resources and weakly patterned economic structures that impede free flow of goods and services. Common economic structures reduce asymmetric shocks and promote trade flows. Despite the relative observed low level of asymmetric shocks, the benefits due to common currency in the zone may be marginal. On the other hand, the results suggest that fiscal policy distortion is the main cost of adopting a single currency. Several studies have reported that most countries of Africa particularly the sub-Sahara nations exhibit fiscal policy inefficiency that distorts macroeconomic stability. Similarly, seigniorage has often been used to finance deficits in Africa. The study shows that loss of monetary policy autonomy will be very monumental given the high level of costs due to fiscal policy distortions. The intuition derivable from this study is that fiscal policy concerns is more critical than shocks pattern in the discussion of monetary union as revealed by the current Euro zone crises.

\section{Conclusion}

This study has endeavored to estimate the costs and benefits of a common currency for the second West African Monetary Zone (WAMZ). The empirical analyses utilized panel data econometric technique. A striking revelation of the study is that the degree of the response of exchange rate to changes in the terms of trade in the zone is relatively smaller than the results suggested by earlier studies. The result indicates fiscal policy distortion in the zone is high and largely influenced by high disposition to money creation. The potential benefits of common currency are likely to be marginal. The prominence of fiscal dominance is a policy challenge to not only individual countries' but also on the sustainability of monetary unions. Fiscal policy distortion negates the effectiveness of monetary policy and influence the manipulation of monetary policy instruments. Thus, forming a monetary union with member(s) with such tendencies implies that the cost due to loss of monetary policy sovereignty could be monumental despite the expected trade creation benefit. It is therefore recommended that the integrating countries should intensify effort to achieve the convergence of key macroeconomic policy indicators through the improvement of their fiscal operations.

\section{References}

Anyanwu, J. C. (2003). Estimating the Macroeconomic Effects of Monetary Union. West African The Case of Trade and Output. African Development Review, 15(2-3), 126-145.

Aisen, A. \& Veiga, F. J. (2005). The Political Economy of Seigniorage. IMF Working Paper, WP/05/175.

Baldwin, R. E. (1998). Review of Theoretical Developments on Regional integration in Areola Oyejide, Ibrahim Elbadawi and Paul Collier (ed), Regional Integration and Trade Liberalization in SubSahara Africa, vol. 1, ST Martins Press, New York.

Balogun, E. D. (2008). An Alternative Reconsideration of Macroeconomic Convergence Criteria for West African Monetary Zone. MPRA Paper No.113, Munich.

Bayoumi, T. \& Eichengreen, B. (1992). Shocking Aspect of European Monetary Unification. National Bureau of Economic Research Working Paper No. 3949. 
Bergman, M. (1999). Do Monetary Unions Make Economic Sense? Evidence from the Scandinavian Currency Union, 1893-1913. The Scandinavian Journal of Economics, 101(3).

Blanchard, O. J. \& Fischer, S. (1989). Lectures on Macroeconomics, MIT Press Cambridge thirteen Edition.

Coleman, A. (1999). Economic Integration and Monetary Union. Treasury Working Paper, 6(2), 124-148.

Collier, P. (1991). African Economic Relations. African Affairs, 90(360), 339-56.

Debrun, X., Masson, P. \& Pattillo, C. (2010). Should African Monetary Unions Be Expanded? An Empirical Investigation of the Scope for Monetary Integration in Sub-Saharan Africa. IMF Working Papers $\mathrm{WP} / 10 / 157$.

Debrun, X., Masson, P. \& Pattillo, C. (2005). Monetary Union in West Africa: Who might Lose, and Why? Canadian Journal of Economics, 38(2), 454-481.

Debrun, X., Masson, P. \& Pattillo, C. (2002). Monetary Union in West Africa: Who might Lose, and Why? IMF Working Paper 02/226: 1-35.

DeGrauwe, P. (2000), Economics of Monetary Union. Oxford University Press: Oxford, UK.

DeGrauwe, P. \& Mongelli, F. P. (2005). Endogeneity of Optimum Currency Areas What brings countries sharing a single Currency closer together. European Central Bank working Paper No. 468.

Dixit, A. \& Lambertini, L. (2001). Monetary and Fiscal Policy Interactions and Commitments versus Discretion in a Monetary Union. European Economic Review, 45, 977-987.

ECOWAS. (2000). Establishment of a Second Monetary Zone in West Africa. Report of the Technical Committee on Monetary Issues. Abuja, Nigeria.

Emerson, M., Gros, D., Italianer, A., Pisani-Ferry, J. \& Reichenbach, H. (1992), One Market, One Money: An Evaluation of the Potential Benefits and Costs of Forming an Economic and Monetary Union, Oxford; Oxford University Press.

Easterly, W. (1999). Fiscal Adjustment and Macroeconomic Performance in Africa: World Bank, Washington D.C.

Ferrari-Filho, F. (2002). Why does it not Make Sense to Create a Monetary Union in Mercosur? A Keynesian Alternative Proposal. Journal of Post Keynesian Economics, 24(2), 235-252.

Frankel, J. A. \& Rose, A. K. (1998). The Endogeneity of the Optimum Currency Area Criteria. The Economic Journal, 108(449), 1009-1025.

Glick, R. \& Rose, A. K. (2001). Does a currency Union affect Trade? The time series Evidence. NBER Working Paper 8396, Cambridge, M.A.

Hefeker, C. (2008). Fiscal Reform and Monetary Union in West Africa. Journal of International Development, 22, 86-102.

Ingram, J. C. (1972). The Case for the European Monetary Integration" Princeton University. Essays in International Finance, 98, 24-59.

Iyoha, M. A. (2003). A Common Monetary Policies for the West African Monetary Zone: Rationale and Design. West African Financial and Economic Review, 1(1).

Kenen, P. B. (1969). The Theory of Optimum Currency Area: An Eclectic View. In R. A. Mundell and A. Swoboda. Eds., Monetary Problems and International Economy. Chicago: University of Chicago press, pp.41-60.

Kenen, P. B. (2004). Transatlantic Relations and the Global Economy. The North American Journal of Economics and Finance, 15(2), 149-159.

Kronberger, R. (2004). A Cost-Benefit Analysis of a Monetary Union for MERCOSUR with Particular Emphasis on the Optimum Currency Area Theory. Economic Working Paper Archive. EWPA/0407/0407010.

Krugman, P. R. \& Obstfeld, M. (2000). International Economics: Theory and Policy" Addison-Wesley Publisher, New York.

Masson, P. \& C. Pattillo, C. (2001). Monetary Union in West Africa: An Agency of Restraint for Fiscal Policies? Journal of African Economies, 11, 387-412.

Masson, P. \& Pattillo, C. (2002). Monetary Union in West Africa (ECOWAS). Is it Desirable and How could it be achieved? IMF Occasion Paper 204, 1-17.

Masson, P. \& Pattillo, C. (2004). A Single Currency for Africa International Monetary Fund (IMF). Finance and Development, 4, 9-15.

McKinnon, R. (1963). Optimum Currency Areas. American Economic Review, 53(4), 717-25.

Mongelli, F. P. (2002). New Views on the optimum Currency Area Theory What is EMU telling us: European Central Bank Working Paper No.138 
Mongelli, F. P. (2005). European Economic and Monetary Integration, and the Optimum Currency Area Theory.

Mongelli, F. P. (2010). On the Benefits and Costs of a Monetary Union. Center for Economic Policy Research (CEPR). Policy Insight, 46, 1-10.

Mordi, C. N. (2003). The Challenges of Monetary Union: Risks and pitfalls and how to respond to them. Central Bank Economic and Financial Review, 3(2).

Mundell, R. A. (1961). A Theory of Optimal Currency Areas. American Economic Review, 51, 657-665.

Nieberding, R. (2004). Optimal Government Finance and Democracy in Developing Countries. Journal of Economic Development, 29(2), 131-147. .

Nnanna, O. J., Essien, E. A., Onwioduokit, E. A. \& Adamgbe, E. T. (2007). Empirical Evidence of the Benefits of Economic and Monetary Integration in the West African Monetary Zone. West African Journal of Monetary and Economic Integration, 7(2).

Ogunkola, O. (2001). An Evaluation of the Prospects of a Single Monetary Zone in ECOWAS Final Report Submitted to the African Economic Research Consortium (AERC), Nairobi, Kenya.

Ogunkola, O. (2005). An Evaluation of the Viability of a Single Monetary Zone in ECOWAS. AERC Research Paper 147, Nairobi, Kenya.

Ogunkola, E. O. \& Jerome, A. (2005). The Future of a Single Monetary Zone West African. West African Journal of Economic and Monetary Integration, 2(1).

Ogunleye, E. K. (2008). Financial Globalization and Macroeconomic Performance in Sub-Saharan Africa: Evidence from Nigeria. African Journal of Economic Policy, 15(1), 1-44.

Ricci, A. L. (2008). A Model of an Optimum Currency Area, International Monetary Fund Research Department.

Rose, A. K. (2000). A Meta-Analysis of the Effect of Common Currencies on International Trade. Journal of Economic Survey, 19(3) 347-365.

Rose, A. K. \& Engel, C. (2001). Currency Unions and International Integration. Journal of Money, Credit, and Banking, 34(4), 1067-89.

Sims, C. (1980). Macroeconomics and Reality. Econometrics, 48, 1-49.

Soyibo, A. (2000). The Challenges of Monetary Integration in West Africa, UN-ECA, Sub-Regional Development Centre for West Africa, Niamey.

WAMI. (2008). Single Currency for the ECOWAS: Options and Prospects. Working Paper No. 12/08, Accra Ghana.

World Bank. (1994). Adjustment in Africa: Reforms and the road ahead. Washington D.C.

World Bank. (2008). World Bank Development Indicator.

Zika, J. (2006). Costs and Benefits of a Monetary Union European Economic Policies: IES FSV, UK. 